\title{
EMERGING MODELS OF THE EVENTFUL CITY
}

\author{
GREG RICHARDS
}

NHTV Breda and Tilburg University, Tilburg, The Netherlands

\begin{abstract}
Cities around the world are increasingly using events as a tool to generate a wide range of effects, including image enhancement, income generation, and social cohesion. However, the use of events as an urban policy tool is hampered by the fact that events themselves also have their own objectives, such as making a profit or advancing the agenda of national and international organizations. In some cases, the objectives of the events and the city may coincide, but in other cases, they may not. Therefore, for cities there is a growing challenge in coordinating their events program in order to maximize the benefits for the city as a whole, while also supporting individual events. Many cities have already developed specific events policies and support mechanisms, but these tend to treat events as individual occurrences, rather than as an integral part of the urban ecology. Richards and Palmer have argued that the "eventful city" needs to take a strategic, holistic view of its events portfolio in order to move from being a city full of events to developing "eventfulness." This article considers how some cities are developing more holistic approaches to event policy and eventfulness. In reviewing the events policies of cities worldwide, it identifies three emerging policy models: event-centric policy, sector-centric policy, and network-centric policy. The article further considers the implications of these different models for events and events policies in cities.
\end{abstract}

\section{Key words: Eventful cities; Urban events; Event programs; Event portfolios; Urban regimes;} Governance

\section{Cities and Their Events}

There has always been a close relationship between cities and events. Cities provide the stage upon which a great number of events unfold, and events provide the catalytic energy that drives urban development. In the modern era, this relationship has crystallized into a series of models or strategies related to the way in which cities utilize events to synchronize agendas, develop externalities, and attract attention. Growing attention for such models has generated a steady flow of contributions to the events literature dealing with the city-event relationship (e.g., Gratton \& Henry, 2001; Hall, 2006; Peters \& Pikkemaat, 2005; Richards \& Wilson, 2004; Smith, 2012; 2015; Whitson \& Macintosh, 1993).

The first main stream of literature on cities and events deals with the broad nature of events, and the role of cities as scenarios in which events take 
place. Some of the early work in this area took its lead from Foucault's (1980) concept of "eventalization," which identifies the process by which events are removed from their historical context and become seen as empty signifiers, bereft of meaning. This is essentially the development that Häußermann and Siebel (1993) identified in their concept of "festivalization," or the development of urban policy through events.

Attention for processes of festivalization marked a concern with the transformation of urban centers into consumption spaces, spearheaded by urban administrations keen to attract the affluent middle classes. This process was fueled by economic and social restructuring processes and the perceived need for global attention, particularly in compensation for the declining attention paid by nation states to cities. Festivalization served as a tool for city governments to create attractions, increase identification of residents with the city, develop public consensus, and establish common goals.

The widespread nature of festivalization was also captured in Tschumi's (1994) idea of the "event city," in which the architecture of the city is increasingly influenced by the event. Sabaté i Bel, Frenchman, and Schuster (2004) also later introduced the concept of "event places" to denote the way in events increasingly owed their existence to the qualities of certain places, and in turn came to influence the way in which these places developed. Increasing attention for the relationship between events and places also led to the realization that different events, or types of events, could have differing effects on the places in which they are staged. Pløger (2010) drew on Foucault's concept of eventalization to underline the distinction between the urban as a scenario for spontaneous "presence events" and top-down, planned "serial events." Presence events, such as the Pirate Parties held in the Danish capital Copenhagen are equated with eventalization, as they have the potential to challenge and change existing structure (Richards, 2015a), whereas top-down serial events are seen as instances of "eventification." "Eventification," according to Jakob (2013), involves a rendering of the space of the city as a series of time elements, increasing the use value of space. Therefore, in the city time and space are intimately bound to each other.
Therefore, the debate on the relationship between events and cities has passed through a number of stages, from a relatively general notion of festivalization to a more structured consideration of the role of events as social and spatial actors in cities (Richards \& Palmer, 2010). It is against this background that the "eventful city" concept first emerged. This concept derived from the observation that cities were beginning to treat events not as discrete happenings in discrete spaces, but as temporal and spatial tools to utilize urban resources in order to achieve a range of policy outcomes for the city as a whole. This is the basis for the definition later proposed for the eventful city: "An eventful city purposefully uses a programme of events to strategically and sustainably support long-term policy agendas that enhance the quality of life for all" (Richards, 2015b, p. 40).

A number of different cities around the globe have embarked on such broader eventful city strategies in the last few years. This article looks at the ways in which the eventful city has developed in the context of three very different European citiesEdinburgh, Rotterdam, and Den Bosch-and to trace the links between their different approaches and urban context. First, we consider the general integration of events and urban processes over time.

\section{The Development of Urban Event Organization}

According to Richards and Palmer (2010), the growth of cities marked a shift of events from the religious into the secular sphere, with a growing use of events as forms of display and spectacle. This in turn led to the growth of specific event spaces, such as the market square or the parade ground. Initially, events were highly regulated and limited to specific days or times marked out for collective celebration. Events were supposed to serve the rational needs of urban society for commerce, festivity, and relaxation, and there was widespread prohibition of events and/or gatherings outside these legitimized spaces and times.

The rational serving of urban needs continued into the industrial era, as cities sought to profile themselves first as national and then international centers for trade and industry. There was a purposeful use of (mega-)events as a means of 
demonstrating the power of the city (Roche, 2000). In the modern era there was a fairly rigid hierarchy to the events world, with the major events taking place in the capital city, sponsored by the nation state, or in the 20th century also by supranational organizations (such as the International Olympic Committee or FIFA).

However, in the postindustrial era the erosion of national spheres of influence under globalization saw cities redefine themselves in the face of global competition. There was a search for new meanings and narratives as cities sought to position themselves, and events began to provide a basis for placemaking strategies, image enhancement, and employment creation (Hixson, 2010). The increasing integration of events and urban policy led to the emergence of what Rennen (2007) has termed "City Events,” involving different stakeholders including civic administrations, commercial companies, the media, and national governments. Therefore, the role of the city moved from the direct organization of events towards a more faciliatory role, in line with increasingly neoliberal policies. In particular, mega-events were analyzed as a vehicle for urban policy (Hall, 2006).

In spite of this growth, there has been relatively little research on the relationship between urban policy and event programs. Antchak (2016) argues that the study of regional event policies conducted by Whitford (2004) in South East Queensland's Sunshine Coast, Australia is one of the few studies to directly address public event policy. However, in recent years more cities have begun establishing new event development agencies responsible for planning and realization of city event projects (Getz, 2012). Thus, in turn has attracted more attention to the causes and effects of urban events policy, leading in some cases to highly critical analyses of neoliberal event policies and management strategies (Rojek, 2014).

In recent years, cities have begun to seek increased flexibility and funding possibilities through the formation of arms-length organizations for event organization and management. As Smith (2012) argued in the case of London, neoliberal policies are driving a growth in the staging of commercial events in cities, increasing the challenges of coordination. Many cities are now operating “one stop shops” for event organizers in order to streamline the process of applying for permits and organizing resources for events. Cities now position themselves in terms of their ability to provide support for event organizers:

In New Orleans, celebration is a way of life. With over 400 cultural, entertainment, and sporting events, our city has more events than days in the year. New Orleans is uniquely positioned and skilled at supporting events-large and small, simple and complex. (New Orleans, 2016)

For many cities, the aim is to support a portfolio of events that will deliver a range of benefits to the city and its stakeholders (Ziakas, 2014). Antchak (2016) analyzed the relationship of event portfolios in the New Zealand cities of Auckland, Dunedin, and Wellington and showed that each city has a distinct approach to the development and management of its portfolio. This underlines the need to analyze the policy context in which event activity develops.

\section{Influences on Urban Event Policy}

As events became recognized as a legitimate sphere for urban policy, cities developed specific event policies intended to guide the development and management of events taking place in the city. Studies emerged of events policy and how cities could successfully encourage or grow events to produce beneficial outcomes. Many cities also developed specific departments or offices dedicated to overseeing events policy and/or attracting new or footloose events. Although the development of event policy was widespread from the 1990s onwards, it was by no means universal, and some cities were more enthusiastic and/or successful in their development of event-based policies. Around the turn of the Millennium, a number of cities also began to develop policies that exploited the relationship between events and wider urban policy agendas. For example, Manchester developed a program of "Pillar Events" in 2005, focusing on events such as the Manchester Jazz Festival, Manchester Pride Parade, Manchester Food and Drink Festival, and Manchester Literature Festival that were seen as having particular significance for the city and/or significant externalities (Manchester City Council, 2011). 
In particular, some authors have attempted to link the development of event strategies to specific types of "urban regimes." Stone $(1989,2005)$ argued that local governments can only govern effectively by entering into long-term alliances with other interest groups in the city, such as businesses, social groups, or development organizations. These relatively stable coalitions he termed "urban regimes," which have specific "agendas" or aims that they come together to support. Interestingly, Stone's original work in Atlanta focused among other things on how the urban regime in the city managed to attract and organize the 1996 Olympic Games in the face of considerable internal and external challenges. The Atlanta regime arguably used the Olympic Games to put the city on the global map, attract visitors to the city, and create economic impacts. These are fairly typical aims of what Stone characterizes as a "development regime." Later work has confirmed the strong link between mega-events and development regimes (Heying et al., 2002; Hiller, 2003). Heying et al. (2002) concluded that Olympic bids follow the pattern of growth regime politics, implying that mega-event bidding suits the desires of business leaders rather than elected officials or city residents. "The bidding process is conducted in such a way as to limit the accountability of bid organizers to public officials or citizens” (p. 193).

Misener and Mason (2008) also looked at the relationship between sports strategies and urban regimes. Reviewing the strategies of Edmonton, Canada; Manchester, UK, and Melbourne, Australia, they found that a more progressive regime in Edmonton used events to facilitate a wider range of civic goals that the economic development regimes in Manchester and Melbourne, which were focused on using events to attract capital and investment. Concentrating on the Olympics, Surborg, VanWynsberghe, and Wyly (2008) also argued that economic growth regimes now also have a transnational dimension, with "policy networks" linking different cities and allowing them to learn from each other about events and event policies.

The growing use of (mega-)events for economic goals linked to neoliberal policies and globalization has also caused people to question what is driving such developments. For example, Fleischer, Fuhrmann, Haferburg, and Krüger (2013) argued that "a hegemony of festivalized middle-class civic culture” (p. 5242) is in evidence in many cities pursuing event-led development policies. Similarly, Haferburg and Steinbrink (2017) showed the ways in which international organizations such as FIFA or the IOC override the normal decision-making processes in the host city, effectively imposing their own set of laws for the duration of the event.

These studies have emphasized that events are increasingly integrated into general urban policies. Events have become more than individual happenings: they have become policy tools that can be used to further a wide range of different agendas in different cities. A further point that has not been considered in previous studies is that once events become an important element on the policy agenda of a city, they can begin to influence the direction of the policies and structures that created them. Events effectively become "actors" in the urban system, to the extent that sustaining, developing, or attracting events becomes a policy goal in itself (Richards, 2015a). The idea that events have become central to the policy agendas of cities is one of the key observations that prompted the original development of the "eventful city" concept by Richards and Palmer (2010).

The new centrality of events in urban policy agendas arguably reflects a legitimization of events as a policy tool by a wider range of stakeholders, which in turn is influenced by the shift from narrow models of urban government to broader systems of urban governance (Stone, 1989). This raises the question of how cities can adapt their events policies to cope with the increased protagonism of events in cities and the growing claims of different urban agendas on their events programs. Does the program or portfolio of an eventful city develop in response to topdown strategy, or is it the product of stakeholder negotiation? This article aims to examine different ways in which "eventful city" models have developed and to analyze their relationship to broader urban structures and processes in an attempt to answer these questions.

\section{Strategies for Eventfulness}

In their original review of "eventful cities," Richards and Palmer (2010) identified a number of cities that could be described as "eventful," including Barcelona, Edinburgh, Rotterdam, Montreal, 
Melbourne, and Singapore. The defining characteristic of these cities is that they all take a strategic view of events, and utilize their events program as a whole to achieve wider civic goals. In most cases there has been a gradual development of "eventfulness," often beginning with certain hallmark events and then developing into a strategic programming approach. Although all of these cities could be said to possess an identifiable "portfolio" of events, eventful cities arguably do more than manage or develop their events portfolio. They also see events as important catalysts that can be used to synchronize policy agendas, solidify stakeholder networks, and increase identification among citizens.

Although the use of events as an urban policy tool is a defining characteristic for eventful cities, not all these cities have developed eventfulness in the same way. Comparison of different cities reveals a high level of path dependency, with clear links between economic structures, urban regime type, and eventfulness policies.

The following sections compares three different ideal types of eventful city policies: event-centric, sector-centric, and network-centric. These are not presented as representative of particular types or groups of cities, rather the analyses are developed as a heuristic device to illustrate ideal cases. This analysis has been developed largely based on a study of relevant literature, including policy documents in the areas of events, tourism, and culture. This is supported in some cities by interviews with policy makers and data taken from event impact analyses and other original research.

\section{Event-Centric Eventfulness}

At the most basic level, cities can concentrate on developing the number, range, and type of events they stage in order to create more eventfulness. Many cities are now thinking about how they can program events in order to support the overall objectives of the city. Such strategies usually focus on event policy, programming, and management.

This is a relatively narrow strategic focus, which centers on the identification of new event-related products and markets. The most common measures taken include the establishment of an events unit to coordinate event policy and management and the development of an overall event programming strategy (e.g., Bianchini \& Parkinson, 1993; Whitford, 2002).

Examples of this kind of strategy include the Antwerpen Open organization in Antwerp, Belgium and Edinburgh Festivals in Scotland. In the case of Antwerpen Open, the city itself was instrumental in developing and funding the event-coordination body for the city. The idea arose during the European Capital of Culture (ECOC) event staged in the city in 1993. Antwerpen Open was responsible for the event program of the ECOC, managing municipally funded events directly and liaising with the organizers of other events in the program. Once the ECOC ended, the experience was so positive that the city decided to continue funding Antwerpen Open, and gave it a remit to oversee the city's cultural program (Antwerpen Open, 2005). Antwerpen Open also became a model for other Belgian cities, most notably Bruges, which established Brugge Plus to manage the ECOC in 2003. The main characteristic of these organizations is that they generate almost all of their funding from the Municipality.

Probably because of the origins of the organization in the ECOC, Antwerpen Open operated mainly in the field of the arts. For example, it organized the van Dyck Year in 1999 and the World Book Capital and Rediscover Rubens in 2004. Even though it was also involved with the fashion theme year "Mode 2001," Antwerpen Open did not fully engage with the city's iconic fashion sector, reflecting a lack of marketing support for fashion that is still felt today (Goesaert et al., 2015; Pandolfi, 2015). As Goeseart et al. noted, fashion events held in the city are mainly picked up by the specialist fashion press in other countries rather than by the domestic press.

In 2015, Antwerpen Open was integrated into Antwerpen Kunstenstad (Antwerp Art City). In this form, it is responsible among other things for supporting "the objectives of cultural events of the City of Antwerp" and "promoting the city of Antwerp as a cultural city in Belgium and abroad."

In contrast to Antwerp, where event policy has been driven by the Municipality, Edinburgh's eventfulness is driven by the main festivals themselves. The main Edinburgh International Festival was founded in 1947, and since then many important festivals have developed in the city, producing a total audience of over 4 million. Edinburgh became a prime international "festival city," but at the turn 
of the Millennium it began to experience growing competition as other cities in the UK and elsewhere began to develop their own festivals. This was the cue for the 12 main Edinburgh festivals to commission the Thundering Hooves study (AEA Consulting, 2006), which recommended creating an ongoing forum to "ensure the long-term health" of the festivals. Because of this recommendation, the festivals came together to form Festivals Edinburgh in 2007. This body is "an expression of the twelve festivals' collective will” (Edinburgh Festivals, 2015, p. 20). It is largely grant funded, and has to be small and lean. Edinburgh Festivals has done a lot to generate knowledge on the Edinburgh Festivals, and events in general, through the Festivals Lab.

In particular, this example of bottom-up development reveals some of the important issues related to this event-focused model. As the original Thundering Hooves report on the festivals strategy of Edinburgh revealed, the festivals themselves tend to have their own sectoral view of the world. Therefore, the Edinburgh Film Festival sees itself operating primarily within a circuit of film festivals, rather than being part of a festival economy in the city of Edinburgh. There may also be a certain rivalry between the festivals in the city, as they tend to regard public sector finance as a zero-sum game in which increased funding for one festival means reduced funding for others. In some cases, the different festivals may also begin to compete among themselves, often dividing into established versus newer events. This underlines one of the potential weaknesses on an event-centric approach, namely that benefits accruing to the events sector may not spill over into other sectors of the economy or city life in general.

\section{Sector-Centric Eventfulness}

A sectoral approach to eventfulness is often based on an understanding that events have a much more significant role beyond the immediate impact of the events themselves. Sectoral strategies see events as important platforms for particular economic, social, and cultural activities in the city. Therefore, the development of eventfulness can be related to all the stakeholder groups that can benefit from and support events. These can include both direct stakeholders who stand to gain economically or politically from the events policy (e.g., as is largely the case in Edinburgh), and indirect stakeholders who will gain from the general growth in economic, social, or cultural activity and the increased concentration of knowledge and resources in the city (Richards \& Palmer, 2010).

Examples of sector-centric strategies include Rotterdam; Dubai; Austin, Texas; and Montréal. In these cities events have become part of broader economic and social policies aimed at developing the city as a whole. In Montréal events such as the Festival International de Jazz de Montréal, Just for Laughs Comedy Festival, FrancoFolies, MUTEK, and the Circus Arts Festival have provided essential support for the development of the tourism, entertainment, and creative sectors in the city (Tourisme Montréal, 2014). Austin labels itself the Music Capital of the World, and the leading role of the music industry makes this a natural focus for development. In addition to SXSW, the city also stages the Austin City Limits Music Festival, the Urban Music Festival, the Kerrville Folk Festival, and the Austin Reggae Festival. These events focus attention on the city and bring leading actors in the creative industries together there.

A sectoral focus provides opportunities to develop certain events into "Field Configuring Events" (Schüßler \& Sydow, 2013) that act as major global or international hubs within a certain economic, political, or cultural field. For smaller cities, such events offer a world stage for a limited period of time, such as the Cannes Film Festival, which focuses global attention on this small French city for a few days.

In Rotterdam, as in Antwerp, the Municipality established an events organization following the ECOC event (held in 2001). Rotterdam Festivals was created as an arms-length organization, with considerable public funding but formally outside the Municipal organization. As in the case of Antwerpen Open, Rotterdam Festivals also had a remit for cultural programming, particularly aimed at increasing cultural participation among Rotterdammers.

The mission of Rotterdam Festivals is summarized in their Annual Report (2015), which underlines that the organization seeks to reach a large, broad audience with events that are characteristic of the identity of the city and which support the city's events sector: 
We are looking for festivals that create meaningful experiences for visitors and that emphasise the identity of the city of Rotterdam. . . . We are still the most appealing event city of The Netherlands and we reach a broad audience through (inter) national appealing programming where our cultural institutions, architecture, diversity of people and cultures, and harbours are the main focal point. (Rotterdam Festivals, 2016)

Therefore, the activities of Rotterdam Festivals have become broader that the events sector alone, embracing other sectors in the search for distinctive events and a distinctive identity for the city. One of the ways that this has been achieved is to identify strong sectors in the city's economy, and to develop events that showcase these in the city and for an international audience. Examples include the World Harbour Day, the International Film Festival, and the World Food Festival. The latter was created by Rotterdam Festivals in 2013 to coincide with the opening of the Markthal, a food-based attraction and marketplace. The Markthal was used as a centerpiece for the event, which attracted 80,000 visitors.

\section{Network-Centric Eventfulness}

The value of a network-based approach to city events has been explored in some detail by Stokes (2006). Network-centric strategies reach out beyond the city itself to connect with stakeholders elsewhere who can help to generate "network value." Richards and Colombo (2017) define network value as: "the value that can be created through the linkages provided by a network, above the value created by the links available to individual network members alone” (p. 75). Seeing events as an important focus for activities within the city is just one part of the potential of events. Their greatest effects can often lie beyond the city itself, in their ability to tie the city into broader global networks and to make it a hub for economic, social, and cultural activity.

In the case of the eventful city, the key lies in conceptualizing the city itself as a network actor. Following Castells' (2009) terminology, when a city takes an active role in networks, it can position itself as a "switcher" that links different networks together. As a switcher in global networks, the city can perform a vital role in linking local "programmers" (responsible for the local content of events) with global networks, providing new opportunities and ideas. Two cities that have managed to position themselves as switchers in different ways are Den Bosch in the Netherlands and Barcelona in Catalunya.

The Dutch city of 's-Hertogenbosch (Den Bosch) made extensive use of the creative industries in its program of celebrations for the 500th anniversary of the death of the painter Hieronymus Bosch in 2016. This event aimed to attract large numbers of tourists, and to strengthen the creative and cultural fabric of the city by bringing Bosch to life, using his artistic legacy as a creative inspiration for the future. The interesting challenge for Den Bosch is that it does not have any pictures by Bosch, as his surviving paintings are scattered across the world. Therefore, the city has had to develop a creative tourism product based entirely on intangible assets, including the creativity inspired by Bosch's work and the storytelling potential of being his birthplace (Marques, 2013).

Particularly important elements of the program are the Bosch Research \& Conservation Project and the Bosch Cities Network. The Bosch Research \& Conservation Project is researching the work of the painter, validating and discovering new artworks, and restoring many of them. These activities increase our knowledge of Bosch's work, and help to establish the position of Den Bosch as a global hub of expertise and knowledge. The Bosch Cities Network links the cities where Bosch artworks are present in museum collections. The network cooperates around research, restoration, performing arts, and visual arts. Most importantly, the network has been used as a means of securing works by Bosch for the Major exhibitions of Bosch paintings (in 's-Hertogenbosch in February-May 2016 and in the Prado in Madrid from June-September 2016). Over 420,000 visitors saw the exhibition Visions of a Genius in 's-Hertogenbosch, about 25\% of whom were international tourists. Even more importantly the city attracted attention from the global media, in particular for "achieving the impossible" in mounting the exhibition (Kennedy, 2015).

By linking tourism and the creative industries, the city has overcome limitations in the supply of cultural heritage resources, developed the creative 
capacity of the city, forged international networks to gather creative resources, and focus visitor attention and engaged citizens through the development of grassroots creativity. A city that was previously reliant on the heritage of the past has creatively linked itself to new sectors such as gaming and design to engage new visitor markets and extend its product portfolio. This case particularly illustrates how the creative sectors can help destinations reach new markets, extend their creative activities internationally, and use clusters and networks to leverage added value.

In the case of Barcelona, there is no shortage of tangible or intangible resources on which to base eventfulness. In fact, the "festive culture" of the city includes some 6,000 popular festivals and local events every year. Over 500 organizations are involved in these events, which are organized with the active participation of 117,718 people (Ajuntament de Barcelona, 2013). This festive culture has helped to put Barcelona on the map as a major tourist destination, to strengthen the creative industries in the city, and to increase social cohesion (Richards, 2015a). However, the strategic development of event policy in Barcelona is dominated by major events such as the World Mobile Congress, EIBTM, and Bread and Butter, all of which generate significant economic impact (e.g., GSMA, 2016). One of the ways in which Barcelona has been able to attract and secure major events is through the use of its international networks. A good example of this is the 2004 UNESCO-sponsored Universal Forum of Cultures - a year-long event that was held for the first time in Barcelona thanks to the city's lobbying with UNESCO. Even though the event itself was not so successful (Richards \& Palmer, 2010), Barcelona managed to secure a position as the home of the Forum, and future editions of the event have all been selected and organized with the help of Barcelona. Therefore, the event continues to provide a global platform for Barcelona and Catalan culture, even though it is now held in distant locations. This strategy of establishing the city as an events "hub" is also seen in the case of the Sonar Electronic Music Festival (Richards \& Colombo, 2017), which has developed satellite events around the world that focus attention on Barcelona as the origin of the event.

\section{Discussion}

The examples of different models of eventfulness presented here illustrate the very different directions that cities can take in trying to develop themselves as eventful cities. Many cities still have a fairly traditional top-down model of event organization, with the city setting, funding, and monitoring policy. In other cases, most notably in Edinburgh, the growth of events has produced a situation in which the events sector itself begins to take a much more active role in policy. In many places, public funding cuts have also forced events to develop a more mixed funding model, which draws a greater range of stakeholders into the event arena. This mirrors the development of urban governance models as a whole, which have also seen a shift away from top-down policy making into regime politics and the development of policy agendas driven by broader coalitions of civic actors.

In the cases analyzed here, the different cities all show signs of a shift towards broader stakeholder engagement, but the actual governance structures show a high level of path dependency that reflects the political, economic, social, and cultural history of the city. For example, both Rotterdam and Antwerp are industrial and port cities that have attempted to address economic decline through the creation of a broad economic development regime. The power of key sectors in the urban economy has led to a concentration on particular types of events linked to these sectors. In Antwerp, the difficult political situation has weakened coalition formation, and therefore the ability of new economic sectors to influence the direction of agenda setting (Pandolfi, 2015). This is evident in the case of the fashion industry, which although it enjoys a high international profile, has not been able to attract the resources necessary to establish regular international fashion events in the city (Goesaert et al., 2015). The situation in Rotterdam is different, because Rotterdam Festivals have been able to take a more strategic view of the events that the city needs to develop in order to create distinction and to link to major economic sectors in the city (Rotterdam Festivals, 2015). Therefore, there is a fairly good "fit" between the strong economic development agenda of the regime in Rotterdam and the types of events promoted by Rotterdam Festivals. 
Edinburgh provides a contrasting example because as the capital city of Scotland it has not suffered so much from economic adversity, and has therefore been able to maintain a broader remit for festival policy. The Edinburgh Festivals also thrived in a relatively generous subsidy climate that enabled them to establish a powerful position in the city. The festivals themselves are now able to use their considerably political clout (backed by judicious use of research showing their economic, cultural, social, and political value to the city) to influence the agenda of the city as a whole.

A lack of economic problems in Den Bosch was also one reason why the city was not successful in an earlier joint bid for the European Capital of Culture title (Marques \& Richards, 2015). However, the city has faced other challenges, including a lack of physical resources related to its key cultural icon, Hieronymus Bosch. The population of the city is only 143,000 , and because of this it cannot compete effectively with neighboring Eindhoven or Rotterdam in terms of staging large events. There are also no major economic sectors that could be used to spearhead new event development. The solution has been to use the networks of the city to focus attention on Den Bosch at one particular moment in time-the celebrations of the 500th anniversary of Hieronymus Bosch's death in 2016. The network created around his artworks produced considerable leverage that would normally only be available to much larger cities. Therefore, the 2016 Bosch exhibition has attracted an audience that would normally only be possible in Amsterdam or Rotterdam.

One of the interesting points emerging from these analyses is the way that events or event programs themselves begin to affect the agenda setting of cities. In the past events have usually been viewed as simple tools that can be used to address the different needs of the city. However, as events grow as part of the urban "software," they also have important effects on other areas of policy themselves. However, the extent to which events can shape policy agendas depends on their position in the urban regime, and on the collective consciousness of the events sector or other sectors that can utilize events. Therefore, the ability of cities to develop eventfulness is dependent on a wide range of factors, which include the structure of the governance regime, the coherence of different urban actors, and the structure of the urban economy.

\section{Conclusions}

This brief review shows that eventfulness can be developed in many different ways, and that each city will have its own strategy, affected by the context, resources, and creativity of the city itself. The interplay of these factors over time will influence the extent to which a city can become "eventful." Over time, some ideal types of eventful city strategies have begun to emerge, including the use of event-based, sector-based, and network-based strategies. Depending on the type of strategy adopted, the skills, knowledge, and resources required for successful implementation will also vary.

In order to engage with a wide range of urban stakeholders and to compete successfully in the global events arena, cities will need to think beyond the creation of a varied program or portfolio of events. The governance arrangements made for developing events will in itself have a significant impact on the range and types of events needed for successful eventfulness. Depending on the governance context, the event program will have to support different aims and objectives, and therefore utilize different performance indicators. For example, in an event-centric environment it may be sufficient for performance to be based on outputs such as visitor numbers, profile, spending, and media attention, because these measures fit with the aims of the individual events themselves. For sectoral-based policies, more attention will need to be paid to the different ways in which events support economic activity, including the development of knowledge, innovation, and image. For networkbased event policies attention needs to be focused on the creation of "network value" (Richards \& Colombo, 2017), which is a measure of the outputs generated by the network as a whole over and above that which the city could achieve on its own.

\section{References}

AEA Consulting. (2006). Thundering hooves: Maintaining the global competitive edge of Edinburgh's festivals. Full report. London, UK: AEA Consulting.

Ajuntament de Barcelona. (2013). Impacte del movement festiu a Barcelona. Barcelona: Author. Retrieved from 
http://www.slideshare.net/Barcelona_cat/impacte-delmoviment-festiu-a-barcelona

Antchak, V. (2016). Event portfolio design: Exploring strategic approaches to major events in New Zealand. Ph.D. thesis, Auckland University of Technology, Auckland, New Zealand.

Antwerpen Open. (2005). Jaarverslag. Antwerp, Belgium: Author.

Bianchini, F., \& Parkinson, M. (1993). Cultural policy and urban regeneration: The West European experience. Manchester, UK: Manchester University Press.

Castells, M. (2009). Communication power. Oxford, UK: Blackwell.

Edinburgh Festivals. (2015). Thundering hooves 2.0. Edinburgh, Scotland: Author.

Fleischer, M., Fuhrmann, M., Haferburg, C., \& Krüger, F. (2013). "Festivalisation" of urban governance in South African cities: Framing the Urban social sustainability of mega-event driven development from below. Sustainability, 5, 5225-5248.

Foucault, M. (1980). Power/knowledge: Selected interviews and other writings 1972-1977. London, UK: Harvester Press.

Getz, D. (2012). Event studies. London, UK: Routledge.

Goesaert, T., Gerdes, E., Heuvelman, M., Heynderickx, Y., Schrauwen, J., Schramme, A., \& Téblick, M. (2015). Onderzoek naar de impact en toegevoegde waarde van Mode in Antwerpen. Antwerp, Belgium: Antwerp Management School.

Gratton, C., \& Henry, I. (2001). Sport in the city: The role of sport in economic and social regeneration. London, UK: Routledge.

GSMA. (2016). 2016 GSMA mobile world congress surpasses record 100,000 visitors. Retrieved from http:// www.gsma.com/newsroom/press-release/2016-gsmamobile-world-congress-surpasses-record-100000-visitors/

Haferburg, C., \& Steinbrink, M. (2017). Mega-events in emerging nations and the festivalization of the urban backstage. The cases of Brazil and South Africa. In J. Hannigan \& G. Richards (Eds.), The SAGE handbook of new urban studies (pp. 267-290). London, UK: SAGE.

Hall, C. M. (2006). Urban entrepreneurship, corporate interests and sports mega-events: The thin policies of competitiveness within the hard outcomes of neoliberalism. Sociological Review, 54(2), 59-70.

Häußermann, H., \& Siebel, W. (1993). Die Politik der Festivalisierung und die Festivalisierung der Politik. Große Ereignisse in der Stadtpolitk. In H. Häußermann \& W. Siebel (Eds.), Festivalisierung der stadtpolitik. Stadtentwicklung durch große projekte (pp. 7-31), Wiesbaden, Germany: Springer VS.

Heying, C. H., Burbank, M. J., Andranovich, G., Andranovich, G. D., Andranovich, G., \& Burbank, M. (2002). Megaevents, urban development, and public policy. Review of Policy Research, 19(3), 179-202.

Hiller, H. H. (2003). Mega-events, urban boosterism and growth strategies: An analysis of the objectives and legitimations of the Cape Town 2004 Olympic Bid.
International Journal of Urban and Regional Research, 24(2), 449-458.

Hixson, E. (2010). The festival state: Differing perspectives on the role of events. Paper presented at the Global Events Congress IV-Events and Festivals Research: State of the Art, July 2010, Leeds Metropolitan University, Leeds, UK.

Jakob, D. (2013). The eventification of place: Urban development and experience consumption in Berlin and New York City. European Urban and Regional Studies, 20(4), 447-459.

Kennedy, M. (2015). Dutch museum achieves the impossible with new Hieronymus Bosch show. The Guardian. Retrieved from https://www.theguardian.com/artandde sign/2015/oct/21/hieronymus-bosch-exhibition-hollandsmall-museum-host-largest-ever

Manchester City Council. (2011). Report for information. Report to: Communities and neighbourhoods overview and scrutiny, committee. Retrieved from http://www.man chester.gov.uk/download/meetings/id/12519/8_informa tion_and_overview_report

Marques, L. (2013). Constructing social landscape through events: The global project of 's-Hertogenbosch. In G. Richards, L. Wilks, \& M. de Brito (Eds.), Exploring the social impact of events (pp. 84-94). London, UK: Routledge.

Marques, L., \& Richards, G. (2015). Bidding for success? Impacts of the European capital of culture bid. Scandinavian Journal of Tourism and Hospitality, 16(2), 180-195.

Misener, L., \& Mason, D. S. (2008). Urban regimes and the sporting events agenda: A cross-national comparison of civic development strategies. Journal of Sport Management, 22(5), 603-627.

New Orleans. (2016). Special events center. Retrieved from http://www.nola.gov/special-events/

Pandolfi, V. (2015). Fashion and the city: The role of the "cultural economy" in the development strategies of three Western European cities. Delft, Netherlands: Euberon.

Peters, M., \& Pikkemaat, B. (2005). The management of city events: The case of "Bergsilvester" in Innsbruck, Austria. Event Management, 9(3), 147-153.

Pløger, J. (2010). Presence experiences - the eventalisation of urban space. Environment and Planning D: Society and Space, 28(5), 848-866.

Rennen, W. (2007). CityEvents: Place selling in a media age. Amsterdam, Netherlands: Amsterdam University Press.

Richards, G. (2015a). Events in the network society: The role of pulsar and iterative events. Events Management, 19(4), 553-566.

Richards, G. (2015b). Developing the eventful city: Time, space and urban identity. In S. Mushatat \& M. Al Muhairi (Eds.), Planning for event cities (pp. 37-46). Ajman, United Arab Emirates: Municipality and Planning Dept. of Ajman.

Richards, G., \& Colombo, A. (2017). Creating network value: Sónar Festival Barcelona as a global events hub. In J. Armbrecht, E. Lundberg, T. Andersson, \& D. Getz 
(Eds.), The value of events (pp. 73-86). London, UK: Routledge.

Richards, G., \& Palmer, R. (2010). Eventful cities: Cultural management and urban revitalisation. London, UK: Routledge.

Richards, G., \& Wilson, J. (2004). The impact of cultural events on city image: Rotterdam cultural capital of Europe 2001. Urban Studies, 41(10), 1931-1951.

Roche, M. (2000). Mega-events and modernity: Olympics and Expos in the growth of global culture. London, UK: Routledge.

Rojek, C. (2014). Global event management: A critique. Leisure Studies, 33(1), 32-47.

Rotterdam Festivals. (2015). Jaarplan en begroting 2015. Rotterdam, Netherlands: Author.

Rotterdam Festivals. (2016). What we do. Retrieved from http://www.rotterdamfestivals.nl/about-rotterdamfestivals/what-do-we-do/

Sabaté i Bel, J., Frenchman, D., \& Schuster, J. M. (2004). Event places. Cambridge, MA: MIT Press.

Schüßler, E., \& Sydow, J. (2013). Organizing events for configuring and maintaining creative fields. In C. Jones, M. Lorenzen, \& J. Sapsed (Eds.), Oxford handbook of creative industries (pp. 284-300). Oxford, UK: Oxford University Press.

Smith, A. (2012). Events and urban regeneration: The strategic use of events to revitalise cities. London, UK: Routledge.

Smith, A. (2015). Events in the city: Using public spaces as event venues. London, UK: Routledge.
Stokes, R. (2006). Network-based strategy making for events tourism. European Journal of Marketing, 40(5/6), 682-695.

Stone, C. N. (1989). Regime politics. Lawrence, KS: University of Kansas Press.

Stone, C. N. (2005). Looking back to look forward: Reflections on urban regime analysis. Urban Affairs Review, 40(3), 309-341.

Surborg, B., VanWynsberghe, R., \& Wyly, E. (2008). Mapping the Olympic growth machine. City, 12(3), 341-355.

Tourisme Montréal. (2014). Annual report 2014. Retrieved from http://documents.tourisme-montreal.org/MontrealTourism/R-and-D/Statistics/EN/ra-2014-en.pdf

Tschumi, B. (1994). Event cities. Boston, MA: The MIT Press.

Whitford, M. (2002). The Ipswich events corporation: Policy directions-Past, present and future. In L. Jago, M. Deery, R. Harris, A. Hede, \& J. Allen (Eds.), Events and place-making: Proceedings of international research conference, Sydney 2002 (pp. 729-755). Sydney, Australia: Australian Centre for Events Research.

Whitford, M. (2004). Event public policy development in the Northern sub-regional organisation of councils, Queensland, Australia: Rhetoric or realisation? Journal of Convention and Event Tourism, 6(3), 81-100.

Whitson, D., \& Macintosh, D. (1993). Becoming a world class city. Sociology of Sports Journal, 10, 221-240.

Ziakas, V. (2014). Planning and leveraging event portfolios: Towards a holistic theory. Journal of Hospitality Marketing \& Management, 23(3), 327-356. 
Copyright of Event Management is the property of Cognizant, LLC and its content may not be copied or emailed to multiple sites or posted to a listserv without the copyright holder's express written permission. However, users may print, download, or email articles for individual use. 